\title{
Theory, Reality, and Possibilities for a Digital/Communicative Socialist Society
}

\author{
Dimitris Boucas
}

University of Westminster and LSE, London, UK, d.boucas@lse.ac.uk

\begin{abstract}
Digital capitalism is guided by the organising principles of digital automation, information processing, and communication. It rests on the consolidation of relations of exploitation of digital labour based on flexibility and generating precarity. It makes profit from user data under conditions of surveillance. What would an alternative paradigm look like? This paper aims to sketch a possible socialist society resting on digital technology but organised on a different logic, namely that of autonomous production, leisure, and social engagement. It draws on relevant theories of the Left, evaluates them against the reality of digital capitalism, and suggests structural and user practice alternatives that can pave the way towards a digital/communicative socialism. This paper engages with the works of Czech philosopher Radovan Richta (1924-1983) and Austrian-French philosopher André Gorz (1923-2007). It shows that their ideas on the scientific and technological revolution and post-industrial socialism are highly relevant for the analysis and discussion of digital/communicative socialism.
\end{abstract}

Keywords: digital socialism, digital capitalism, Internet, digital labour, platforms, monopolies, surveillance, social production, user practice, Radovan Richta, André Gorz

Acknowledgement: The author wishes to acknowledge with warm appreciation the insightful comments of Christian Fuchs to earlier versions of this article.

\section{Introduction}

Contemporary capitalism is to a large extent determined by the pervasiveness of digital technologies of automation, information processing and communication. Such technologies have established a networked informational capitalism. This form of capitalism rests largely on the layered Internet infrastructure which is a sine qua non for communication, organisation, business, economic, social, political, and cultural activity.

Contemporary capitalism has deployed information and communication technologies (ICTs) to perpetuate and deepen social relations of exploitation of (digital) labour in the organisation of a global production and delivery of products and services. It has done so partly by exploiting the flexibility offered by digital technologies to drive down work and pay levels. It has also engaged effectively the general citizen/consumer in a global interconnected system where online activity generates data, which become the currency of business models of large monopoly high tech corporations in the media and communications industries.

What seems to be absent, under these circumstances, is a possibility for an alternative digital paradigm that could harness digitisation for purposes of autonomous production, increased leisure and emancipation from the limitations of wage labour. Such an alternative paradigm could be termed digital/communicative socialism or digital/communicative socialist society.

The aims of the paper are: Firstly, to set the contours of a possible digital socialist society drawing on conceptualisations of the Left provided by Radovan Richta and 
André Gorz. Secondly, to project these conceptualisations to the contemporary character of digital capitalism. Thirdly, to identify ways in which the contemporary, platform and monopoly-based capitalism can gradually give way towards what might be in the future become a form of digital/communicative society.

The argument in the paper is that although digital capitalism in its current form falls short of the emancipatory promise of technological development, a digital socialist society is possible. However, it will be premised on radical transformation of the existing infrastructure of digital capitalism, as well as change in user engagement with digital technologies.

The next section will sketch the dimensions of digital socialism as they have emerged from selected theorisations of the Left on technological development and the post-industrial society. Section 3 will measure these dimensions up to the reality of contemporary digital capitalism. Section 4 will explore the possibilities of alternatives and pathways towards what can gradually resemble a digital/communicative socialist society; in doing so it will draw on recent intellectual attempts towards this direction and, to a small extent, on survey data about user engagement with the current Internet. Section 5 will conclude, summarising theory, reality, and possibilities.

The paper draws more specifically on the theorisations on the post-industrial society by Radovan Richta and André Gorz.

Richta, a Czech philosopher, was born in Prague in 1924 and died in 1983. He was a pivotal figure in the communist reform movement in Czechoslovakia around the time of the Prague Spring and the blatant military intervention of the Soviet army forces.

During World War II, he was part of the communist resistance against the Nazis. Imprisoned for several months, he was rescued by the Red Cross as he was suffering from tuberculosis. After the War and between periods of illness, he organised an interdisciplinary research team, whose most famous work was Civilisation at the Crossroads, a collection of articles first published in Czech and Slovakian in 1967, then in an English translation in 1968 and a French one in 1969. Richta's name is associated with the concept of the scientific and technological revolution (Richta 1967).

Gorz, an Austrian/French social philosopher and journalist, was born in Vienna in 1923 as Gerhart Hirsch and died in 2007. In 1949, he moved to Paris, and started working for Paris-Presse under the pseudonym Michel Bosquet, and subsequently for L'Express as an economic journalist. In the 1960s and 1970s, he became part of the New Left movement that was inspired by humanist Marxism and promoted a left agenda in issues of work, including equality, justice, liberation and a guaranteed social income. In 1961, Gorz entered the editorial committee of Les Temps Modernes. In 1964, he co-founded Le Nouvel Observateur weekly. He befriended Herbert Marcuse and Ivan Illich and brought their works to a French audience. Gorz followed closely the events of May 1968 in Paris that he saw as having the potential to realise his humanist socialist vision. Throughout his life, he engaged with a number of topics, as evidenced in his diverse books, such as Ecology as Politics (Gorz 1979), Paths to Paradise (Gorz 1985) and the famous Critique of Economic Reason (Gorz 1989). His work Farewell to the Working Class (Gorz 1982) is the most relevant for the purposes of our analysis.

The paper draws on the work of these two thinkers as they had a lot in common: both were Marxist/socialist humanists, both were heavy critics of the Soviet Union regime, and both were proponents of a humanist/democratic socialism.

More importantly, both Richta and Gorz seem to have been "displaced" from the mainstream literature on information society. Their names are not entirely absent. Richta is mentioned as a key theorist of the growing importance of information technology in society in Beniger's (1986) book The Control Revolution. However, more 
established textbooks on theories of the information society (e.g. Castells 1996; Webster 2014) have not engaged with the works of Richta and Gorz. In this sense, the current paper redresses the balance by bringing their ideas forward in a discussion of the contemporary character of the digital society; and in the imaginaries of the future digital/communicative socialism.

\section{Theory: The (Socialist) Digital/Communicative/Information/Network Society}

Already in the Grundrisse, Marx (1973) is eloquent about the importance of scientific and technological evolution for the development of capital's productive forces, the ensuing application of science to production and the increasing significance of knowledge labour. The so-called Fragment on Machines, in particular, highlights the effect of technology in reducing necessary labour time and creating conditions for communism, free time as a source of wealth and the development of a rounded personality (artistic, scientific and so on) during the freed time. But, it also stresses that this emancipatory potential is embedded in a context of capitalist class relations where the socialised productive forces clash with the relations of production leading to lack of autonomy, precarity and unemployment (see Fuchs 2015).

Since the early 1950s and 1960s, the left thinking has sought to come to terms with the increasing presence of science and technology in production but also in all spheres of economic and social human activity. Radovan Richta (1969) provides one of the early visions of the "scientific and technological revolution" as a "new foundation for civilisation" (65). Whilst industrial production was characterized by increasingly complex machines in production, together with a growing army of labour, the application of science and technology to other spheres of human activity [emphasis added] was limited. This, for Richta, is about to change: the scientific and technological revolution has a more transformative event throughout society overall; not only the objective means of production (e.g. raw materials, capital, labour) change, not only the structure and dynamics of the productive forces, but also the "subjective, human factor" (56).

Richta points to the possibilities for the scientific and technological revolution to overcome the capitalist logic, which determines that labour be broken down into simple operations and that the growth of consumption be restricted. At the heart of his argument is that the advancement of science and technology enables a stable level of production and accumulation. The implication is that labour can possibly escape the routine of mechanised work, while at the same time, forces could be liberated and used for other social purposes (i.e. non-commercial, non-profit and non-accumulation). This is a hopeful prospect: "Only the all-round advance of the scientific and technological revolution can give rise to a new form of civilisation which, as regards both level of development of labour and consumption, corresponds to the requirements of communist society" (65). However, Richta notes that for society to benefit from the scientific and technological revolution, a "revolution in social relations is essential" (61).

Richta's work has been seen as pioneering but also different from the mainstream of communist Czechoslovakia. He saw the scientific and technological revolution as a basis for the transition from capitalism to communism but also from authoritarian to human-centred communism (Fuchs 2015). At the same time, his use of the scientific and technological revolution went beyond the orthodox idea that communism on its own would release the technological forces. He placed emphasis on the new paradigm of services in civilisation and the role of a new service class in the transformation, breaking away from the idea of the working class as central to the coming of the socialist society (Mattelart 2003). 
The logic of Richta's argument is not dissimilar to that of Daniel Bell, the early theorist of the post-industrial society. Bell traces a historical continuity from the pre-industrial to the industrial and post-industrial society by means of rationalisation, which brings greater efficiency and increased productivity within each stage and enables the passage to the next. Rationalisation leads to superfluous labour and increased profits and consumption, driving society first from the agrarian mode to manufacturing (industrial society) and then to services (post-industrial society). In the first stage, it is manual labour and physical power that defines work and societal organisation. In the second, it is technology and the use of energy that constitutes the fundamental social parameters and determines the content of jobs. In the third stage, it is organised knowledge that defines social relations and labour occupations. The decline of manufacturing with the decrease in the number of manual workers, the generation of a number of new service sectors and the overall increase in information-handling tasks and specialities lead to more white-collar occupations and the predominance of information and knowledge (Bell 1973; Webster 2014; Boucas 2010).

Despite similarities with Richta's approach, however, Bell was almost inimical to the Left. A one-time Trotskyist, he later denounced socialism and became over-critical of Marxism and the "European neo-Marxist theoreticians" (including Richta), whose aim, he felt, was "not to illuminate actual social changes in the society but to "save" the Marxist concept of social change and the Leninist idea of the agency of change" (Bell 1973, 39-40).

What constitutes Bell's criticism, though, seems to make Richta's account powerful and different. He certainly claims that automation can free man "altogether from direct participation in the production process. It relieves him from of his role as a mere cog in the machine system and offers him the position of inspirer, creator, master of the technological system, able to stand apart from the immediate manufacturing process" (Richta 1969, 112). Richta $(1969,114)$ adds: "Then, when man stops doing the things that things can do for him, he is offered the prospect of creative activity as the normal occupation through which he can exercise all his powers - activity imbued with scientific elements, discovery, invention, pioneering and cultivating human powers". What is implied in his account, additionally and importantly, is that these developments are far from automatic. "the secret of the present scientific and technological revolution [...] the most effective means of multiplying the productive forces of society and of human life is inevitably found to be the development of man himself, growth of his abilities and creative powers - development of man as an end in itself" (Richta 1969, 43, emphasis in the original).

Science, then, does not develop on its own but is rather the result of human endeavour. Technological and scientific development relies not on structure but agency; Richta's account is humanist Marxism par excellence.

In his book Farewell to the Working Class (1982) André Gorz envisages a society where automation frees up time from work (done for remuneration) to be devoted to other activities that are not for money, but "for the interest, pleasure, or benefit involved". Gorz, however, argues that whatever the social organisation, capitalist or communist, individual autonomy and fulfilment will be always limited and subsumed by the collective societal organisation, market or state. The undermining of personal autonomy and pluralism under socialist doctrines limits socialism in the imagination of the many. It is this sphere of personal autonomy and freedom of expression "against all pressures and external obligations", a sphere of family life, do-it-yourself, personal in- 
terests, communication, relationships, love that should be protected: "a sphere of sovereignty wrested [...] from a world governed by the principles of productivity, aggression, competition, hierarchical disciplines" (Gorz 1982, 80).

Gorz quotes from Marx's Grundrisse: "As soon as labour in the direct form has ceased to be the great well-spring of wealth, labour time ceases and must cease to be its measure, and hence exchange value [must cease to be the measure] of use value. [...] With that, production based on exchange value breaks down, and the direct, material production process is stripped of the form of penury and antithesis. The free development of individualities, and hence [...] the necessary labour of society to a minimum, which then corresponds to the artistic, scientific etc. development of the individuals in the time set free, and with the means created, for all of them" (Marx 1973, 705706; see also the quote in Gorz 1982, 81).

For Gorz, as for Richta, "[t]he manner in which the abolition of work is to be managed and socially implemented constitutes the central political issue of the coming decades". Gorz advocates a guaranteed basic income for all and welcomes a future where "the autonomous production of use-values becomes a real possibility for everyone" (Gorz 1982, 4). At the same time, he argues that the complete abolition of industrial production and the associated "heteronomous" work is not possible. One reason for this is that the tools necessary for the exercise of autonomous work can only be produced by industry, as Illich (1973) proposes. Rather, what is to be aspired to is a considerable reduction in that sphere, accompanied by the augmentation of "autonomous" work. Consequently, Gorz endorses a dual, synergistic societal organisation which will aim at a diminishing share for the heteronomous and an increasing one for the autonomous mode of production through the liberation of time by technological evolution.

This is not going to happen automatically. Only "if it is combined with effective possibilities for autonomous production will the liberation of time point beyond the capitalist logic, wage system and market relations" (Gorz 1982, 5). Autonomous production is incompatible with public or private industrial, commercial or professional monopolies: "Effective possibilities for autonomous production cannot exist for everyone without a policy providing adequate collective facilities for that purpose" (Gorz 1982, 5, emphasis added). Gorz places special emphasis on the role of the state to enlarge the sphere of autonomy at the expense of heteronomy. In parallel, he argues that investing in alternative technologies and practices and experimentation in social production is quite important. The emancipatory promise of technological progress, coming from the writings of Gorz and Richta, then, can be summarised as follows:

- humans will need to work less, particularly in mundane/mechanical work tasks

- humans will be able to engage more in socially beneficial work

- humans will have more opportunities for autonomous, peer production

- humans will have more opportunities for leisure and consumption

In the next section we assess the degree to which such premises correspond to the reality of the contemporary society.

\section{Reality: The Contemporary Digital Capitalist Society}

The theorisation of the scientific and technological revolution and the post-industrial society can be compared to the reality of contemporary digital society. The assessment of the possibilities for socially purposeful activity (i.e. producing social value), and the 
prospects and limits to autonomous production, cannot be conducted without an evaluation of the contemporary digital/communicative society. The early socialist theorists of the information society, as mentioned, were not technological determinists. They argued that science, technology, and information do not generate a new state of affairs by themselves. Richta and Gorz did acknowledge that a transformation of social relations would be necessary for the potential of science and technology (and the digital society) to be harnessed for a socialist agenda and social framework.

Castells, the foremost theorist of the "network society", writing thirty years after Richta and fifteen years after Gorz, has argued that the network society is a new type of societal organisation with its own logic (the network logic) imposed on social and political processes, reconfiguring and redefining them. In this way, the economy becomes informational, global, and networked. The firm is transformed into the network enterprise. Work and employment adopt flexible patterns and continuous occupational mobility. Relationships of production become globalised, labour segmented and social classes less coherent. Consumption patterns become diversified, individualised and unequal, with growing social polarisation. Organisational hierarchies in all organisations are challenged. Culture and meaning become increasingly fragmented (Castells 1996; Castells 1997; Castells 2001).

Castells has been influenced by Alain Touraine and his theory of post-industrial society, which resembles the theory of Bell. He explains that the capitalist crisis of the 1970s coincided with the development of new information and communication technologies, which were put in the services of the dominant capitalist mode of production and transformed society from an industrial to an information mode of development (Castells 1996). This rejuvenated and consolidated the failing capitalist system of the time. The emergent digital society held distinctive capitalist features.

Broadly speaking, Castells belongs to the structuralist school of neo-Marxism and has been influenced by structuralists such as Althusser and Poulantzas, at least regarding his theory of the "network state". It is no coincidence, then, that there is no mention of either Richta or Gorz, who belong to the humanist Marxist school and pay more emphasis on agency and praxis, rather than structure.

In any case, what comes out of Castells' analysis is that the transformation of social relations predicated by Gorz and Richta has not happened. Frank Webster, in a respectable book on theories of information society, identifies global informational capitalism as the dominant force shaping contemporary society. While he does signal differences of this contemporary form from corporate or laissez-faire capitalism, he still argues that there is a continuity with previous societal stages, in that commercialisation and the business and profit logic have been extended and accentuated (Webster 2014).

It is under these present circumstances that the four dimensions of a possible digital/communicative socialist society emanating from Richta's and Gorz's work can be put to the test.

\subsection{Humans Will Need to Work Less, Particularly in Mundane Tasks}

Contemporary thinkers on the left have often engaged with the automation discourse. Srnicek and Williams, for instance, argue that the recent wave of automation will transform the labour market, as "it comes to encompass every aspect of the economy" (Srnicek and Williams 2015, 112). Yet, "automation should entail humanity's liberation from toil, but because we live in a society where most people must work in order to live, this dream may turn out to be a nightmare" (summarised by Benanav 2019, 6). Left accelerationism, a group of thinkers who argue that automation will resolve social 
problems, is also represented in Aaron Bastani's (2019) book Fully Automated Luxury Communism that envisages a society where artificial intelligence and robots liberate humans from labour, where all the needs of humans are met, where there is time for personal fulfilment, non-remunerative careers, unlimited public services and consumer commodities for all. Bastani draws on various thinkers, including the management Guru Peter Drucker but does not mention the work of Gorz and Richta.

Notwithstanding the vision behind his writings, Gorz was not very optimistic about the post-industrial neo-proletariat, which is positioned in an environment of increased automation, faces abolition of work tasks, precarity of work (with utmost flexibility and no security) and, eventually, unemployment. "Technological development does not point towards a possible appropriation of social production by the producers. Instead it indicates further elimination of the social producer, and continuing marginalization of socially necessary labour as a result of the computer revolution" (Gorz 1982, 72).

The implication is that labour becomes more individualised (and without collective class consciousness), each worker focusing on their individual development. At the same time, precarity conceals the real redundancy of labour, and removes the possibility of liberation from it and from the system of social relations that sustains it. Rejection of the accumulation ethic - and human agency towards this goal - is, for Gorz, the only way out of the logic of capital and the system it has generated, which has reached its limits.

It is evident that neither Gorz nor Richta could have anticipated the degree to which digital technological developments have pervaded all industries. The technological landscape has evolved so rapidly that to come to terms with it is an insurmountable task. Indeed, this complexity is demonstrated in the various streams of literature: science and technology studies, management and organisational studies, innovation and critical media literature, to mention a few (Finn 2017; De Nardis 2014; Lobet-Maris 2009).

One dominant feature that stands out is the omnipresence of the Internet, which, understandably, could not have been analysed by Richta or Gorz. To be sure, it is hard to conceive of standalone technologies in contemporary capitalism any longer. The Internet infrastructure, on the whole, is no less than the essential backbone for the digital society to exist. This infrastructure in itself is complex enough, not least because of its layered architecture (Van Dijk 2012). Significantly, it has redefined business strategies, it has given rise to new business models and has reshaped the space of competition and profit-making in the economy.

Furthermore, digital and Internet-based capitalism is globalised and involves a variety of traditional and new forms of labour. Its pervasiveness entails the introduction of digital functions as part of production, delivery and service processes. These developments have led to an explosion of digital work. Following Fuchs (2014), we adopt the following definitions and differentiation between digital work and digital labour.

"Digital work includes all activities that create use-values that are objectified in digital media technologies, contents and products generated by applying digital media" (Fuchs 2014, 352); "Digital labour is alienated digital work: it is alienated from itself, from the instruments and objects of labour and from the products of labour. Alienation is alienation of the subject from itself (labour-power is put to use for and is controlled by capital), alienation from the object (the objects of labour and the instruments of labour) and the subject-object (the products of labour) [...] Examples are slave workers in mineral extraction, Taylorist hardware assemblers, software engineers, professional online content creators (e.g. online journalists), call centre agents and social media prosumers" (Fuchs 2014, 351-352). One can extend the above notions by including 
also in digital work activities that use to a small or large extent digital means to produce non-digital products or services. The smart methods and tools in agriculture, the use of computers in production processes for automobiles and airplanes, and the variety of online services (e.g. customer services) are cases in point.

Digital labour is digital work placed in the framework of capitalism and class society. Such an extended notion embraces a variety of possible forms of labour in digital capitalism and enables a better assessment of where digital labour stands.

In the realm of production, the pervasiveness of the Internet, the deployment of robots, artificial intelligence and smart technologies have given rise to the so-called "Industry 4.0". Automation in the existing capitalist context has generated new forms of organisation of industrial production based in a global organisation of digital labour, which includes factory workers working on products with more or less digital content or engaging with digital means of production.

In the realm of service provision, a lot of repetitive and mundane service labour has been eliminated or replaced by automated or robotic processes, e.g. in customer services. A parallel development is the increasing deployment of platforms, namely "products, services, or technologies that act as a foundation upon which external innovators [...] can develop their own complementary products, technologies, or services" (Gawer and Cusumano 2014, 417). Companies like Apple, Microsoft, Google and Amazon provides their platforms for other parties to use and create business ecosystems. Service provision is often mediated by such platforms, e.g. transport services like Uber and delivery services like deliveroo build their service on platforms such as Google and the Apple iOS; in the process they engage the drivers and delivery workers, the platform labour.

It should also be mentioned that a great deal of service provision has been transferred to the consumer, becoming thus self-service. Businesses organised as platforms have appropriated digital technologies to provide interfaces whereby consumers can perform a variety of service functions - booking, ordering, buying, paying and so on. State authorities have replicated the model in electronic government services. The performance of these actions - often repetitive, often time-consuming - amounts to consumer labour, namely processes where consumers become value-generating workers. What emerges can be termed a "self-service economy" where the worker/employee is gradually abolished and the surplus value appropriated by the business is provided by the customers themselves.

These aspects of global production and service provision suggest that the claim that "humans will work less and will work less on mundane tasks" has not been realised. While, in theory, technology socialises labour, in the reality of digital capitalist society people depend on wages and the global digital economy depends on labour, which through the flexibility of digitalisation and conditions of under-investment has become precarious and under-employed (Benanav 2019). This is exactly the contradiction identified by Marx: the antagonism between productive forces and productive relations within a capitalist class-based framework results in technological development acting as a non-emancipatory force (Fuchs 2015). If anything, labour has been

${ }^{1}$ Industry 4.0 is a term denoting a whole reconfiguration of industrial processes that goes beyond the single automation of a single operation, or set of operations, and involves the digitisation of all physical assets and integration in an ecosystem that includes the firm and its business partners. It involves digitalisation and integration of horizontal and vertical value chain, digitisation of products/services offered, digital business models and enterprise-wide data analytics (Geissbauer 2016). 
extended into the leisure sphere, as consumers have become labourers engaged in the repetitive and mundane tasks dictated by the digital interfaces of the self-service economy.

\subsection{Humans Will Be Able to Engage More in Socially Beneficial Work}

The corollary from the previous discussion is that the circumstances for engagement with more socially-oriented or socially beneficial work are not in place. Under-employment in the capitalist economy, by definition, frees up time (though not due to automation but due to the reduced amount of paid labour). This provides flexibility and generates some opportunity for occupying one's time in alternative ways, many of which could be socially beneficial. However, under-employment in practice means reliance on more than one paid jobs to generate what can resemble a full salary. Precarity and under-employment are part of the picture that Bauman has so eloquently identified in his theorisation of "liquid modernity" and "liquid life" (Bauman 1990; Bauman 2005).

In addition, flexibility and the modular character of work, together with lack of security, create a state of consciousness which eats up the psychological background needed for humans to exercise their social nature. "The individual becomes an isolated monad always looking for new forms of socialisation, which instead of providing safety and welfare, increase the gap between man and the Self and between man and the other. It is a social system that -despite being in possession of increasingly innovative means to communicate and interact with their fellows- generates discomfort and loneliness" (Palese 2013, 2).

This is not cultivation of the individual sphere of creativity, as Marx and Gorz would advise. It is rather the plunging of individualism into consumerism to resolve unhappiness: "The exit from a state of unhappiness can [...] only be through an operation committed by happiness-seekers on themselves, and each one on their own, not by the many seekers after happiness putting their heads together to design the shape of a better world and then joining ranks and working together to make it better" (Bauman 2005, 132).

This does not mean, of course, that individualism has pervaded the entire social fabric. Individualism is a generalisation with limits and there are (and always will be) pockets of social community. It makes sense, then, to consider the organisational premises within which communities (and also individuals) can exercise their productive capacities.

\subsection{Humans Will Have More Opportunities for Autonomous Peer Production}

Peer production (often also "P2P production") "has been broadly portrayed as a generic form of self-organization among loosely-affiliated individuals that volunteer on equal footing to reach a common goal" (Bauwens, Kostakis and Pazaitis 2019, 4). Peer production is mostly associated with creative and knowledge-based work, as it is often organised through distributed means of production (e.g. computer and Internet resources) and is based on information, which is naturally abundant and can be shared without cost. In these circumstances, the argument is that peer production presents advantages over markets, privatisation of information, and managerial or state planning (Benkler 2006).

Autonomous (individual and) peer production rests on at least two suppositions: firstly, a reasonable degree of autonomy and secondly, the presence and availability of knowledge (for personal use and for sharing among peers). As mentioned, autonomy from the necessity of work-for-income does not exist under the present circum- 
stances of digital capitalism. As autonomous peer production is premised on the availability of distributed information and communication resources, the question becomes whether the Internet could compensate by providing the necessary degrees of freedom for autonomous production and availability of knowledge.

In its original conception and decentralised organisation, the Internet gave such opportunities for peer-to-peer engagement and knowledge sharing. Indeed, one might be tempted to argue that the World Wide Web's interface with its ubiquitous access to information, as well as the presence of platforms on which users can generate and share content, obey the premises of autonomous and peer production. Critical analysis, though, suggests that autonomous peer production cannot be reconciled with the current character of the Internet. This is for (at least) two reasons: online surveillance and the privatisation of knowledge.

John Bellamy Foster and Robert McChesney (2011) describe in vivid strokes the ways in which the Internet has become a colonised space for capitalist activity and profit-making. They focus on the processes of Google, Microsoft, Apple and a handful of other companies capitalising on network effects on their platforms through applications and reaping increasing monopoly benefits by creating barriers to entry for competitors: "Competitive strategy in this sphere revolves around the concept of the lockin of customers and the leveraging of demand-side economies of scale, which allow for the creation of massive concentrations of capital in individual firms" (Foster and McChesney 2011, 26).

By exploring the close connections between government policy and monopoly power in the form of the capitalist state's deregulation policies, Foster and McChesney also emphasise that neoliberalism has advanced the demise of a basic pillar of liberal democratic theory, i.e. the separation of public and private interests. The close alliance between corporate power (interested in profits) and state power (interested in surveillance) have shrunk the sphere of political liberty.

Surveillance is indeed a key feature of the contemporary digital society and one that has been well-documented in literature. Lyon (2007) analyses the explosion of personal data through Internet traffic and the processes through which states deploy them for social sorting and profiling in the name of citizen safety, particularly in the post 9/11 era. Power and politics are accompanied by economic processes whereby customer data are invited, stored and traded as valuable commodities in the "surveillance society" (Lyon 2007). The more communication and knowledge are mediated by big corporations that monopolise vital Internet activities (search, social networking, usergenerated digital content, etc.) the more opportunities exist for any individual (online) activity to be recorded, monitored, endlessly stored, recombined, analysed, targeted, etc. with the help of large databases stored on server farms and Al-based algorithms.

Zuboff (2019) sees surveillance as the key distinctive feature of the present digital society. Her focus is on what she calls "behavioural surplus" which is the outcome of online activity and which is utilised by Google and other digital companies as "surveillance assets": "These assets are critical raw materials in the pursuit of surveillance revenues and their translation into surveillance capital. The entire logic of this capital accumulation is most accurately understood as surveillance capitalism" (Zuboff 2019, 94, emphasis in the original).

Understandably, not all production and activity takes place online. However, subjecting online communication and knowledge tools to the checks and monitors of platform capitalism (Srnicek 2016) severely restricts the possibility of autonomous production. 
The other premise of autonomous production is the availability of free knowledge. Broumas discusses the "intellectual commons", which are related to "terrains of mainly intellectual, as demarcated from those of chiefly manual, human activity" and include "social structures related primarily to intellectual work in terms of the production, distribution, and consumption of information, communication, knowledge, and culture, which are subject to dynamic change" (Broumas 2017, 1510).

Broumas identifies the expansion of intellectual commons in processes and instances such as open hardware design, open standards, free and open source software, online content under creative commons licenses, and various collaborative media. All these Internet-mediated activities create a "kaleidoscope of sharing and collaborative innovation", which "constitutes our digitized environments not as private enclosures but as shared public space, a social sphere divergent from the one reproduced by the market and the state" (Broumas 2017, 1507-1508).

The question, however, remains one of the relative weight and presence of such practices compared to profit-making and knowledge-enclosing and privatisation processes and practices over the Internet. We will return to this issue in our discussion of alternatives in Section 4.

\subsection{Humans Will Have More Opportunities for Leisure and Consumption}

The expansion and generalisation of the Internet has meant that many leisure and consumption activities take place in the online environment. Examples include online social communication, online entertainment through a variety of media, or online formation of communities in the realm of leisure.

The present character of the Internet mediates such activities in particular ways and for particular purposes that have nothing to do with the original intention of those (citizens and consumers) who engage in such activities. The question then becomes: what kind of leisure and what kind of consumption can one enjoy in digital/surveillance capitalism?

As with the case of work, leisure presupposes conditions of autonomy. However, digital capitalism has managed to occupy the space of individuality. One consequence is that work and leisure become intermingled. Christian Fuchs notes: "The convergence of work and free time is not automatically a problem in itself if it means that work becomes more playful, social and self-determined. The problem under neoliberalism and capitalism is, however, that productive labour tends to enter and soak up leisure time, resulting in absolute surplus-value production, not the other way round" (Fuchs 2016, 59).

A second consequence is existential in more general terms. Zuboff analyses digital existence in surveillance capitalism, or, in other words, the ways in which surveillance capitalism has conditioned human practice and behaviour. She illustrates how the technologies of digital capitalism act to achieve a programme of "behaviour modification". A quote from one of her company interviewees declares: "The goal of everything we do is to change people's actual behaviour at scale. We want to figure out the construction of changing a person's behaviour, and then we want to change how lots of people are making their day-to-day decisions. When people use our app, we can capture their behaviours and identify good and bad [ones]" (quoted in Zuboff 2019, 296).

Perhaps this role of digital technologies is not something new. As science, technology, and society studies have demonstrated in the last thirty years, the technological artefact, or, even more so, the technological order shapes human behaviour (Bijker, Hughes and Pinch 1987). What is nowadays distinctive, though, is the extent of reach of the digital in all spheres of everyday human existence and the insatiable appetite of 
digital capitalism to generate revenue out of the data of the users (people, citizens, consumers) in all possible ways. As Zuboff notes: "The allure of surveillance revenues drives the continuous accumulation of more and more predictive forms of behavioural surplus" (Zuboff 2019, 296).

Leisure and consumption are not exclusively online activities. However, in the present digital society, as with the case of work, many of these activities have a digital component. This generates user data and possibilities for surveillance. The answer, of course, is not to deny digital technology and engagement with the Internet, but, rather, to seek an alternative organisation of the Internet.

\section{Alternatives: Changes of Structures and Practices}

If contemporary capitalism has harnessed digital technologies for profit maximisation through circumstances of rampant competition; if user engagement with the Internet goes through the obligatory passage points of commercialisation, monopoly, and surveillance; if these dimensions can modify and shape human behaviour, then what remains of digital socialism or the digital/communicative socialist network society?

Our argument is that the socialist network society is possible, provided that there are changes both in social structures and human practices. Giddens's structuration theory has taught that there is always a dialectic between changes in practices and changes in structures (Giddens 1984).

The work of Richta and Gorz can be insightful in the consideration of alternatives, as they both emphasise humanist agency, which takes place within existing structures.

At the level of social structures, material resources and social organisation the commons provide a model towards alternative social arrangements that go beyond market and central state organisation. Yochai Benkler argues: "It is the feasibility of producing information, knowledge, and culture through social, rather than market and proprietary relations - through cooperative peer production and coordinate individual action - that creates the opportunities for greater autonomous action, a more critical culture, a more discursively engaged and better informed republic, and perhaps a more equitable global community" (Benkler 2006, 92).

Benkler explains that commons-based peer production, and social production more generally, are sustainable and efficient ways of organising information production. This is because the information infrastructure is, to all intents and purposes, universally distributed, while the raw materials of the information economy (information and knowledge) are naturally public goods. Here Benkler makes a strong case that the most prudent course for any society is to start from the assumption that the Internet should be fundamentally outside the domain of capital. In doing so, he echoes Foster and McChesney (2011), who apply the Lauderdale Paradox of classical political economy - the contradiction between public wealth and private riches - to the Internet sphere.

Bauwens, Kostakis and Pazaitis (2019) have recently formulated the Commons Manifesto, in which they outline the premises of a peer-to-peer set of production arrangements and social relations in networks where "participants have maximum freedom to connect" (Bauwens, Kostakis and Pazaitis 2019, 1). Their use of the term "freedom" reflects "the material possibility for many-to-many communications on a global scale and the ability of people (peers) to connect, communicate, organise and engage in shared value creation, with little to no restrictions regarding location and time" (Bauwens, Kostakis and Pazaitis 2019, 85). Their model includes a technological infrastructure, which enables a new mode of production (the commons) and the potential for transition to an economy that can be generative, as opposed to extractive. 
Gorz, while somewhat pessimist, would appreciate the commons structures, processes and practices as a possible vehicle for change towards a more socialist digital society. As his humanism is grounded on pragmatism and awareness of the limits to emancipation, his endorsement of alternatives would tally with the current co-existence of intellectual enclosures of knowledge and commons-based sharing and peer production. He would likely have emphasised the importance of the social struggle between the forces of commodification and commonification, the result of which is the intellectual commons (Broumas 2017). Richta (1969), on the other hand, would have seen intellectual commons as the terrain where "the development of human powers" (90) and the "cultivation of human capacities" (44) can materialise through sharing and coproduction of information and knowledge.

All the above point to the centrality of the Internet as a space where the emancipatory promises of digital socialism can be realised. Given the low costs of reproduction of information, digital socialism might be easier to achieve in the realm of the production of digital goods than in the realm of the manufacturing of physical products. There has indeed been ample critical engagement with the possibilities of the Internet for debate, critique, agency, and emancipation (e.g. Atton 2004; Couldry and Curran 2003; Chadwick 2006).

However, social production necessitates a recasting of the character of the Internet.

Morozov (2019), for instance, outlines his prerequisites for a possible "digital socialism". He grapples with more concrete proposals about the ownership of user data and the deployment of Internet infrastructure in ways that enhance solidarity, non-market relations, as well as decentralised planning. His analysis is based on what he calls "the feedback infrastructure", namely the data collected by big corporations (Internet service providers, search engines, social media) through countless traces of online activity - or what is commonly termed "big data"2.

Morozov's claim is that, instead of being a profit generation mechanism, this infrastructure could be used to identify social problems, either of local or of more general importance. Drawing on the work of Stafford Beer's work on the Chilean Cybersynproject under the socialist Allende government in the early 1970s, Morozov argues that decentralised public and civil society institutions, deploying the free and available to all digital infrastructure, could arrive at better solutions than the logic of the market and competition à la Hayek and neoliberalism. Radical democracy should be combined with "radical bureaucracy" and take advantage of the planning and coordination capacities offered by the information infrastructure. Democratisation of artificial intelligence and the socialisation of the feedback infrastructure would be necessary to put user data and the technological mechanisms (algorithms) acting upon them to more socially beneficial use.

Benkler's and Morozov's views are complementary and point to the direction of democratic network/communicative digital socialism. What they are missing, though, is a roadmap through which such a transformation can start. Our argument is that for the above structural changes to happen a change in user practice is also indispensable. This claim is grounded on the work of Gorz and Richta.

Recently, we conducted an online survey ${ }^{3}$ on users' concerns over the current Internet and their views on possibilities for alternatives. The intention of the survey was

${ }^{2}$ We prefer the term "digital means of production" as the technologies of the feedback infrastructure are obviously digital, while the result of their operations is (production of) user data.

${ }^{3}$ Acknowledgement: The results reported are the outcome of work as part of the EU Horizon 2020 project netCommons: Network Infrastructure as Commons, http://netcommons.eu/, grant agreement number: 688768 . 
not to provide representative results, but rather to elicit the opinions of selected groups of knowledgeable, competent and frequent Internet users (academics/researchers, young people/students, university administrators, IT professionals). With that in mind, the recruitment of the participants was carried out through relevant mailing lists ${ }^{4}$.

The responses of the survey on the dominance of Google as search engine and Facebook as social network echo critical literature on the issue: Google and Facebook functioning as single information sources with particular kinds of bias and selectivity algorithms involved; Google and Facebook enjoying a monopoly dominance with significant power as social influence forces; Google and Facebook using business models and practices that are informed by advertising and commercialisation, thus promoting a consumerist culture. They paint a picture of reality-shaping through control of information, the creation of a stratified attention economy (Introna and Nissenbaum 2000), lack of transparency (Lobet-Maris 2009), and surveillance (Andrejevic 2007).

When it comes to the level of practice and preparedness of the user to engage in alternative practices, however, the picture is more ambiguous and equivocal. The relevant questions in the survey read:

- "Would you consider using alternative platforms instead of Facebook, Twitter, YouTube or Google, if this choice would provide better control of your data and privacy?"

$46 \%$ mentioned they already used or would use privacy-friendly alternative platforms, $43 \%$ said that changing to alternatives would depend on the behaviour of their friends.

- "Would you consider using alternative platforms instead of Facebook, Twitter, YouTube, or Google, if this choice would mean receiving no advertisements?" $41 \%$ already use or would use advertising-free alternative platforms, $45 \%$ have said changing to such alternatives would depend on the behaviour of their friends.

Respondents also provided open-ended answers which illustrate this ambivalence further ${ }^{5}$. Many express their dislike regarding Facebook, but still consider it necessary for communication. Their aversion can be due to commodification, advertisements, policies, or aesthetics ( $r 124, \mathrm{r} 345)$. They show awareness that interactions are monitored for targeted advertising but still use it as a platform enabling them to stay in touch with

${ }^{4}$ The design of the online survey questionnaire has been based on the inclusion of different categories of questions, separated in five sections labelled from A to E. After a short explanation of the aims of the questionnaire and the provision of the relevant consent form (in A), Section B, drawing on other similar surveys, includes a set of questions about the Internet usage and the digital skills of the respondent. Subsequently, Section $C$, which can be seen as the core section of the questionnaire, addresses various concerns that the respondent might have as an internet user, relating to areas such as: a) privacy and data control, b) digital labour and advertising c) monopolies of information provision, d) Internet governance and electronic democracy. Section $D$ explicitly asks respondents to consider community networks as an alternative and also seeks to elicit their views as to the potential of such networks. Finally, Section E includes demographics of the respondents, as well as certain attitudes that they might have towards life and society, which might be indicative of the likelihood to support community initiatives. The full results of the survey are available as open data under the Creative Commons Attribution Non-Commercial NoDerivatives International 4.0 License (CC-BY-NC-ND 4.0) at: https://zenodo.org/record/1294040.

${ }^{5}$ Some of the statements are provided here in direct or indirect speech with the respondent number in parentheses. However, this is only a fraction of responses to illustrate the tensions and ambiguities in using digital media platforms. 
friends worldwide ( $r 525, \mathrm{r} 529, \mathrm{r} 1059)$. Many respondents confess that "there is little I can do but submit to it" (r201); "If most people use Facebook, what can I do?" (r63). Despite their concerns many users feel they cannot pull out of Facebook (r801, r807) and that they will accept the terms of service (r884). Not being on Facebook is equivalent with exclusion from the professional and social groups and their dynamics (r353). It becomes almost compulsory to use it and use nothing else (r431).

As a result, many users are prepared to compromise the security of their data and privacy for the sake of convenience, though they do not like this (r702, r1160). Others do not even think in terms of privacy and data security, but rather of the opportunities for communication provided ( $r 712)$, or understand the business model and try to be selective with the data that they post (r1469).

We also found ambiguous results when it comes to use of Google services. Google is generally considered a superior search engine. Some respondents, however, are aware that other search engines are available ( $r 649, \mathrm{r} 924, \mathrm{r} 1148)$ and that one is free to choose (r707). Many, however, are not informed of the alternatives that exist (1310, 2050) or do not know where to find them (815). The fact that there are not visible or used shows that people do not care (305). Some respondents stress that it is a matter of personal choice and one should understand that they should be careful and decide to what extent they want to share their data and make use of the services of these large corporations (r567). They point to the degrees of freedom that users have with regard to Google: from ignoring the ads to not looking into the top results, which include the Google preferences, or not clicking into those results (843).

What emerges from the survey is a tension associated with users' engagement with Facebook and Google that points to a more generalised ambiguity of user practice visà-vis the Internet. One side of the ambiguity is the possibility of choice. Greenfield summarises it in an eloquent, albeit one-sided manner: "Nothing forces anyone [...] to sign up a profile on Facebook, search with Google, or use Apple computers, and there remain wide swathes of the planet where one can go weeks without overtly encountering any of their products and services. What's more, even in their core markets their dominance is of a relatively recent vintage, and it's unwise to ascribe to these particular enterprises a long-term tenacity and persistence they have yet to demonstrate" (Greenfield 2017, 284). None the less, from the perspective of the user, "choice" is accompanied by non-participation and social exclusion and these effects are more pronounced in particular demographics, not least the young generation which relies more on social media than any other form of communication. The pseudo-choices available can be seen as coercion and they force users to comply and participate under the terms and conditions dictated by the Internet monopolies.

These results are relevant in a discussion about the possibilities of alternative Internet organisation. User practice generates networks effects and reinforces the business models of large monopoly corporations that dominate the Internet and ascribe to it its current commercial, monopolistic, privatised and surveillance form. By the same token, the absence of these networks effects would render the very monopoly power void. As every user engagement with the artefact (the platform, the search engine, the social network, the software code) is, in the final analysis, negotiable and not absolutely stable and determined (Bijker, Hughes and Pinch 1987), the character of the Internet can possibly change leading to potential transformations in the overall digital/communicative capitalist society as is currently experienced. 


\section{Conclusion}

On the basis of the above discussion, the contemporary digital society, in its current form, cannot serve the emancipatory promise inherent in technological development. The promises of digital/communicative socialism for less work, more time, more social engagement, more autonomous production and more leisure have not been hitherto realised.

The non-severance of the work/income relationship means that liberation of time is accompanied by precarity of work. In parallel, the flexibility of digitalisation is linked to the rise of the self-service economy and increases the bureaucratic and administrative demands on the individual.

The conditions of autonomous production are absent, or at least not satisfactory, in a digital society with increased surveillance and insufficient ownership (through artificial scarcity) of information.

Leisure is delimited by the intrusion of work in daily life with the "always on" condition of network and digital connectivity.

Individualism boosted by precarity and competition seals the tomb of social engagement which is diminishing in observable ways (or becomes framed by the rules of the game of Google and Facebook).

Work, production, and leisure are all subjected to the same regime of behaviour manipulation and colonisation of subjectivity, a digital form of alienation dictated by online engagement mediated by powerful monopoly and commercial interests which rely on the private feedback infrastructure of user data.

Whilst departure from digital technologies is not a possibility, departure from the current state of affairs should be kept in sight as the only route towards the digital/communicative socialist society. Gorz's analysis of alternatives and the co-existence of heteronomous and autonomous spheres leads to the importance of the commons as alternative societal organisation and philosophy. The emphasis on human powers, placed by Richta in his discussion of scientific development, needs also to be central in the imaginary of digital socialism. Praxis and agency are at the heart of Richta's and Gorz's post-industrial socialist-humanist theories. We argue that the change can start from the digital infrastructure itself and the ways of engagement with it.

This departure can only be achieved by a combination of policy emanating from state and decentralised authorities at the regional, local and community level, together with changes in user practices at the individual, group, and family level. Gorz himself emphasised the role of the state: "The existence of a state separate from civil society, able both to codify objective necessities in the form of law and to assure its implementation, is thus the essential prerequisite to the autonomy of civil society and the emergence of an area outside the sphere of heteronomy in which a variety of modes of production, modes of life and forms of cooperation can be experimented with according to individual desires" (Gorz 1982, 112).

This will entail a strategy that gradually introduces in the digital infrastructure elements of collective and social production aiming at serving the information and communicative needs of the citizens/users in the most democratic ways, in accordance with the premises of the commons. It will require regulation but also investment in production facilities and digital education and skills to be able to articulate better those user needs. That digital education needs to be part of the policy is the echo of the writings of both Richta ("cultivation of human capacities") and Gorz (who draws on Illich's "tools of conviviality").

User praxis can generate the demand for this strategy, as it can create a void in user engagement with dominant corporations and a call for the conceptualisation and 
establishment of alternative software, applications, platforms, and social organisational entities to carry those out. As the "behavioural surplus" feeds the current digital means of production, a change of practice on the part of the user is able to generate negative network effects, reduce monopoly power and gradually collapse the business models of big data-handling corporations. Alternative Internet user practices, peer production, and coordination with state structures (including municipal and local ones) will be necessary for imagining and realising a more "digital/communicative socialist" network society.

While the outcome is uncertain, the struggles for strengthening the digital commons are far-ranging. Such struggles pose possibilities for achieving a gradual but great disruption of the Internet towards digital socialism. Assuming the continuing significance of Internet infrastructure for business and communication, such struggles might be part of a grand socio-economic disruption of society as totality.

\section{References}

Atton, Chris. 2004. An Alternative Internet: Radical Media, Politics and Creativity. Edinburgh: Edinburgh University Press.

Bastani, Aaron. 2019. Fully Automated Luxury Communism: A Manifesto. London and New York: Verso.

Bauman, Zygmunt. 2012. Liquid Modernity. Cambridge: Polity. 2nd edition

Bauman, Zygmunt. 2005. Liquid Life. Cambridge: Polity.

Bauwens, Michael, Vasilis Kostakis, and Alex Pazaitis. 2019. Peer to Peer: The Commons Manifesto. London: University of Westminster Press.

Bell, Daniel. 1973. The Coming of Post-Industrial Society. New York: Basic Books.

Benanav, Aaron. 2019. Automation and the Future of Work. New Left Review 119: 5-38.

Beniger, James. 1986. The Control Revolution. Technological and Economic Origins of the Information Society. Cambridge, MA: Harvard University Press.

Benkler, Yochai. 2006. The Wealth of Networks: How Social Production Transforms Markets and Freedom. New Haven, CT and London: Yale University Press.

Bijker, Wieber, Thomas Hughes and Trevor Pinch, eds. 1987. The Social Construction of Technological Systems. Cambridge, MA: MIT Press.

Boltanski, Luc and Ėve Chiapello. 2006. The New Spirit of Capitalism. London: Verso.

Boucas, Dimitris. 2010. The Information Society and the State. Unpublished PhD Thesis. London: London School of Economics and Political Science.

Broumas, Antonios. 2017. The Ontology of the Intellectual Commons. International Journal of Communication 11: 1507-1527.

Castells, Manuel. 2001. The Internet Galaxy. Oxford: Oxford University Press.

Castells, Manuel. 1997. The Power of Identity. Oxford: Blackwell.

Castells, Manuel. 1996. The Rise of the Network Society. Oxford: Blackwell.

Chadwick, Andrew. 2006. Internet Politics: States, Citizens, and New Communication Technologies. New York and Oxford: Oxford University Press.

Couldry, Nick and James Curran, eds. 2003. Contesting Media Power: Alternative Media in a Networked World. Boulder, New York, Toronto, Oxford: Rowman \& Littlefield Publishers.

DeNardis, Laura. 2014. The Global War for Internet Governance. New Haven, CT and London: Yale University Press.

Finn, Ed. 2017. What Algorithms Want. Imagination in the Age of Computing. Cambridge, MA: MIT Press.

Foster, John Bellamy and Robert W. McChesney. 2011. The Internet's Unholy Marriage to Capitalism. Monthly Review 62 (10): 1-30.

Fuchs, Christian. 2017. Marx's Capital in the Information Age. Capital \& Class 41 (1): 51-67.

Fuchs, Christian. 2015. Reading Marx in the Information Age. New York: Routledge. 
Fuchs, Christian. 2014. Digital Labour and Karl Marx. New York: Routledge.

Fuchs, Christian and Marisol Sandoval. 2014. Digital Workers of the World Unite! A Framework for Critically Theorising and Analysing Digital Labour. tripleC: Capitalism, Communication and Critique 2 (2): 486-563, DOI: https://doi.org/10.31269/triplec.v12i2.549

Giddens, Anthony.1984. The Constitution of Society. Cambridge: Polity.

Gawer, Annabelle and Michael A. Cusumano. 2014. Industry Platforms and Ecosystem Innovation. Journal of Product Innovation and Management 31 (3): 417-433.

Geissbauer, Reinhard. 2016. Industry 4.0. Building the Digital Enterprise. London: PricewaterhouseCoopers.

Gorz, André. 1989. Critique of Economic Reason. London: Verso.

Gorz, André. 1985. Paths to Paradise: On the Liberation from Work. London: Pluto.

Gorz, André. 1982. Farewell to the Working Class. London: Pluto.

Gorz, André. 1979. Ecology as Politics. New York: South End Press.

Greenfield, Adam. 2017. Radical Technologies: The Design of Everyday Life. London and New York: Verso.

Illich, Ivan. 1973. Tools for Conviviality. London: Calder and Boyars.

Introna, Lucas D. and Helen Nissenbaum. 2000. Shaping the Web. Why the Politics of Search Engines Matters. The Information Society 16 (3): 169-185.

Lobet-Maris, Claire. 2009. From Trust to Tracks: A Technology Assessment Perspective Revisited. In Deep Search: The Politics of Search beyond Google, edited by Konrad Becker and Felix Stalder, 73-84. Innsbruck: StudienVerlag.

Lyon, David. 2007. Surveillance Studies: An Overview. Cambridge: Polity.

Marx, Karl. 1973. Grundrisse. Harmondsworth: Penguin.

Mattelart, Armand. 2003. The Information Society: An Introduction. London: Sage.

Morozov, Evgeny. 2019. Digital Socialism? New Left Review 116/117: 33-67.

Palese, Emma. 2013. Zygmunt Bauman: Individual and Society in the Liquid Modernity. SpringerPlus 2: 191.

Richta, Radovan, ed. 1969. Civilisation at the Crossroads: Social and Human Implications of the Scientific and Technological Revolution. White Plains, NY: International Arts and Sciences Press.

Richta, Radovan. 1967. The Scientific \& Technological Revolution. Australian Left Review 1 (7): 54-67.

Srnicek, Nick and Alex Williams. 2015. Inventing the Future: Postcapitalism and a World Without Work. London and New York: Verso.

Van Dijk, Jan. 2012. The Network Society. London: Sage. 3rd edition.

Van Doorn, N. 2018. The Parameters of Platform Capitalism. Krisis: Journal for Contemporary Philosophy 2018 (1): 103-107.

Webster, Frank. 2014. Theories of the Information Society. 4th ed. London: Routledge.

Webster, Frank. 2002. The Information Society Revisited. In Handbook of New Media: Social Shaping and Social Consequences of ICTs, edited by Leah Lievrouw and Sonia Livingstone, 22-33. London: Sage.

Zuboff, Shoshana. 2019. The Age of Surveillance Capitalism. New York: Profile Books.

\section{About the Author}

\section{Dimitris Boucas}

Dr Dimitris Boucas is Visiting Researcher at the University of Westminster's Communication and Media Research Institute (CAMRI) and Research Fellow at the London School of Economics in the UK. His research interests include digital technology policy, media policy, alternative journalism and social innovation. He has recently completed working on the EU-funded project netCommons, which examines community networks as complementary or alternative to the standard Internet. Dimitris has a degree in sociology from the Open University, UK, a MSc in science and technology policy from the University of Sussex, and a PhD in information 
society and the role of the state (with Greek information technology policy as case study) from the LSE. He has published on information society theory and policy and media policy and has extensive teaching experience in information society, media and communication theory and policy, social media innovation management and qualitative research methods. He has taught at various Universities, including the LSE, the University of Westminster, City University of London, the University of Paris (Dauphine), and the University of Piraeus. 